\author{
\begin{tabular}{ll}
\hline 論 & 説 \\
\hline
\end{tabular} \\ 方向感検 査の臨床応用 \\ 加 我 君 孝

\section{Clinical Application of Sound Lateralization Test} \\ Kimitaka Kaga \\ (Tokyo University)
}

\begin{abstract}
Sound localization in the horizontal plane primarily depends on the interaural time difference (ITD) and interaural intensity difference (IID). When sounds with identical ITD or IID are presented to both ears, the sound image is lateralized to the side receiving the earlier or louder stimulus within the head. Currently, ITD and IID discrimination abilities are separately measured with a commercially available self recording apparatus.

In this review, the history and basic science of sound localization is discussed in detail. Moreover, for future clinical application, sound lateralization abilities of patients with peripheral hearing loss, brain stem disorders, and auditory cortex disorders are described pertaining to discrimination of ITD or IID separately using a self recording sound lateralization system.
\end{abstract}

Key words : sound lateralization, sound localization, interaural time difference, interaural intensity difference, auditory cortex

はじめに

両耳聴は，最近のバーチャルリアリティ技術のらち聴 覚の仮想体験を通じてより身近になっている，歴史的に は両耳聴によって再現される立体音響が身近になったの はLPレコードの開発からであろら．FM 放送が始まる 前，ラジオ放送ではNHK 第 1 が右チャンネル，第 2 が 左チャンネルに分けAMの立体放送がされたことも あった．今では CDにより立体音響の再生も身近になっ た. 両耳聴検査としての応用は, わが国では昭和 30 年代 より行われているが，一般的な検査として普及している とはいえない，かつてはその検査法が特殊で，自分で装 置を作らなければならなかった。最近では市販されてい る製品もあり，コンピューターでソフトウェアを組んで 自分で作ることさえできる. 難聴者に対して補聴器の両 耳装用は一般化し, 人工内耳ですら両耳埋込みの効果も 検討されているが，その基礎的研究は少ない。両耳聴
の効果は単耳聴で得られない特長がある。このらち, selective attention は重要である. 別名, カクテルパー ティ効果といい,これはT.S. Elliotの戯曲, Cocktail Partyからきて特り，パーティのらるさい会話の中から 自分が聴きたい会話のみ聴き取る能力のたと党で，耳が 2 つあって初めて可能である.

本稿では, 両耳聴検査の歴史的発展, その生理学的基 礎, 聴覚系の中耳, 内耳, 脳幹, 大脳の障害に分けてそ の病態生理, そして今後の展望の順に解説を行ら.

\section{歴史}

Gulick $^{1)}$ による解説が詳しい. 以下抄訳し紹介する.

1. 初期の100年間 $(18 \sim 19$ 世紀)

Venturi が直径 $40 \mathrm{~m}$ の円周上にいる正常者や片側難 聴の被験者に, フルート音を聴かせて, “強度差”が真 の音源定位を生むといら説を18世紀末に提案した。その 
後この説は19世紀後半まで多くの学者に受け入れられた. 1877年 Rayleigh は，この説には問題が 2 つることに 気がついた．一つは音源が正中にあるときは前後の定位 が混乱すること，もら一つは両耳聴の軸が前方にある と，後方には関連する位置があって両耳の音圧比が同じ であることである．このことから両耳の強度差が音源定 位の手がかりであり，その差が 0 になると間違いが生じ ると述べ，さらに強度差は周波数の関数で，高い周波数 で最大となり，波形が頭蓋の周囲の長さの 4 倍になると 無視できるとし，周波数の重要性を指摘した. Rayleigh の後も, 技術改良によって “強度差仮説” は Preyer (ヘルメット), Matsumoto（音のカゴ), Thompson (pseudophone) らによっても支持された。19世紀末にな ると, 音源定位と頭部の動きの関連には三半規管や視覚 が重要であると述べる研究者もいた．Labordeの“三 半規管仮説” は, 頭部を動かさない場合の音源定位の説 明ができないが，“聴空間”について考兄させた。音は 三半規管を刺激しないからである．以上より19世紀には (1)両耳の強度差, (2)頭部運動の 2 つが重要であるとされ た。

\section{20世紀初期 (1900～1930)}

Helmholz 飞よると位相差が不協和音の理解に重要で あるが，位相は協和音には重要でなく，「ヒトは phase deaf である」という見解であった。偉大な Helmholz が「位相は知覚されない」といったために，音源定位に 位相が重要であることがわかるまでに時間がかかること になった。1907年, Rayleigh が $128 \mathrm{~Hz}$ の音叉の音を チューブで一方の耳へ, 同時にわずかに違う周波数の音 を反対の耳にチューブで入れると，“binaural beating” が生れることがわかった. “beating tone” は右から左， 前後に動いた，Rayleigh は実験を低周波に限った，強 度差に比べると位相の役割ははるかに小さいと考皇たか らである。

1908年, More, Fry, Wilson, Myers らが低周波数で は位相差が重要であることを明らかにした。すなわち， 両耳強度差は高中音域, 両耳位相差は低音域で重要であ ることがわかった．Mallock は同年，両耳時間差が音源 定位の基礎であることを示した．音源からの音が最も近 い耳に到着するために時間差が生じるといらもので Aggazzotti も1911年と1920年, 時間差が最も重要であると 報告した，そのため，時間差がどの程度関係するか研究 が行われたが Von Hornbostil，Wertheimer が $30 \mu \mathrm{sec}$ であると確定させた．位相差と時間差は同一のものであ る議論もされたが現在は違らことがわかっている。これ 以後, (1)強度差, (2)位相差, (3)時間差が確立する. 両耳 に同一の内容の刺激が入ることを diotic，異なるものが 入ることを dichotic と呼ぶが，現実の世界では，強度， 位相，時間も異なるので dichoticな状況となる。ただ し，正中では diotic になることがある。

1930年飞初めて Békésy が実用的な音像定位の検査法 を考兄，実験を行った(図 1 ).

\section{生理学的基礎}

脳のなかの聴覚伝導路が明らかになったのは20世紀に なってからである．各中継核のなかでニューロンの分布 が見かけ上も不思議な形態をとっているのが上オリーブ

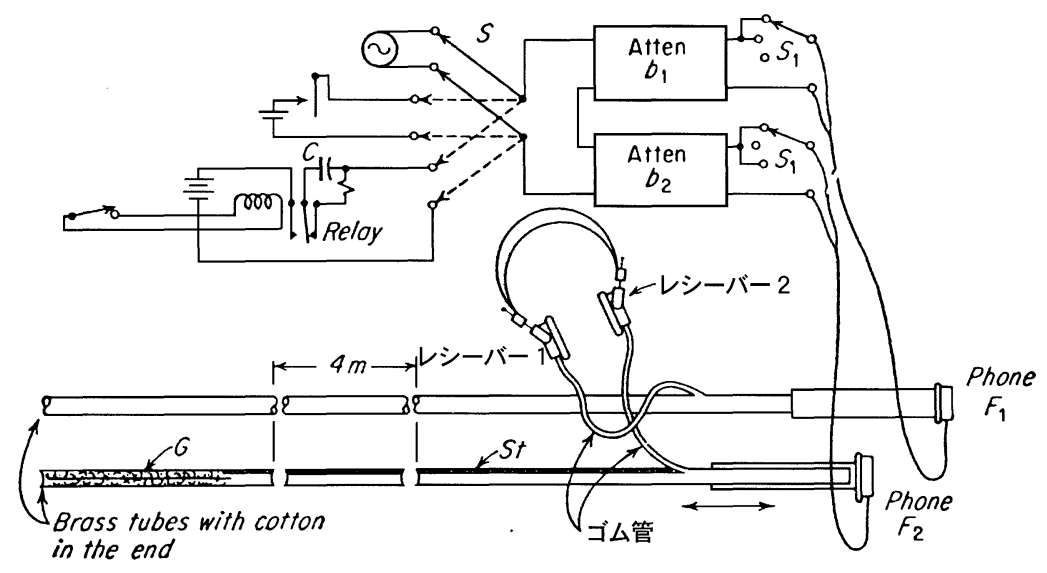

図 1 Békésy (1930)による, 両耳間差による方向感検査のシステム.チュー ブシステムと呼ばれる1). (Békésy GV : 19605) より改変) 


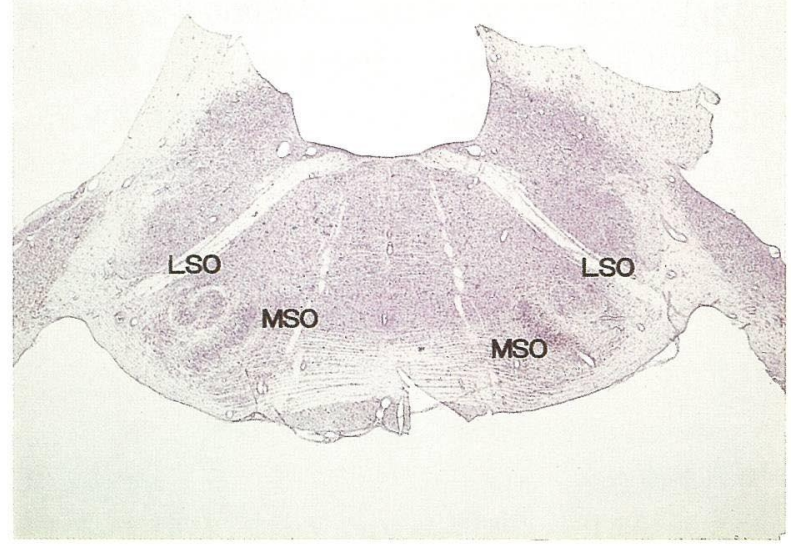

図 2 ネコの上オリーブ核

HRP を下丘に注入乙逆行性に染めたもの.S字状の外 側核 (LSO) とバナナ状の内側核 (MSO) がよくわかる。

核である。これは外側核と内側核からなり，外側核は $\mathrm{S}$ 字状の形をしている(図 2 )。脳のなかにこのような形態 をとる核は他にはない。1953年 Stotler2) は，上オリー ブ核内側核は，両耳に届いた聴覚信号が初めて出会ら部 位であることを示した。図 3 にHRPに染まったニュー ロンの強拡大を示したが，きわめて樹状突起の多いこと がわかる。
1959年, Galambos ら 3 は は内側核のみが両耳よりの入 力を持つこと，30\%は両耳からの反応のみの刺激に応じ， 残りは反対側耳からの刺激のみに応じることを見い出し た.Van Bergeijk は) 次のようなモデルを提唱した。 「片側の蝸牛神経核より上行する神経線維は 2 つ分か れ，一つは反対側の内側上オリーブ核へ，他は同側の内

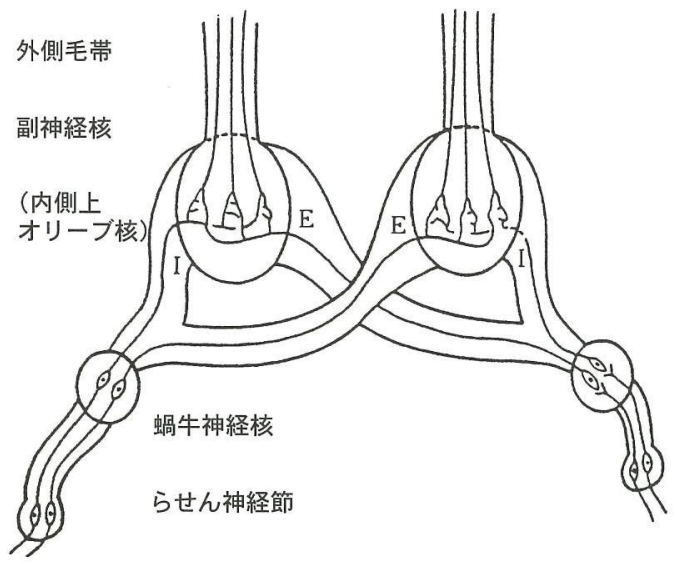

図 4 台形体核上オリーブ核に搞ける両側神経支配の模型図 Stotler 氏細胞の樹状突起が，両側から同時に興奮 $(\mathrm{E})$ と抑制（Ｉ）を受けることを示す. (Van Bergeijk : 19624) より改变)

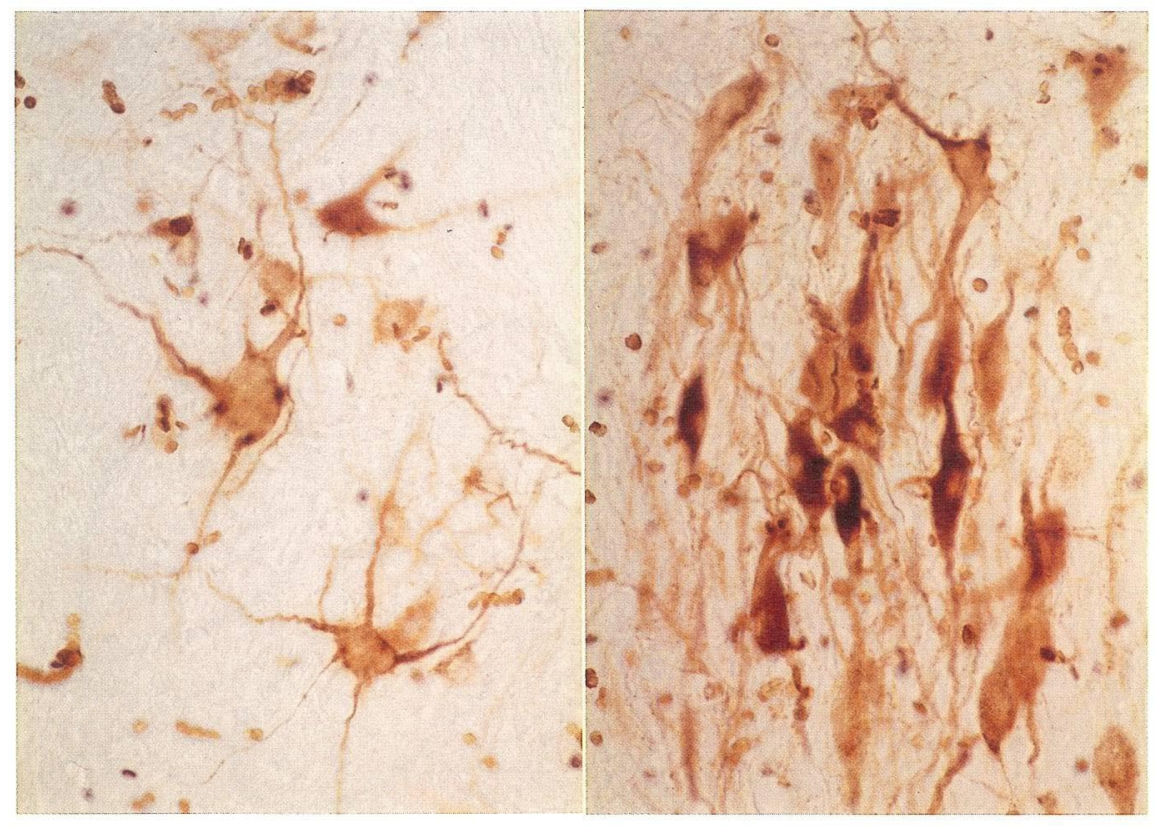

a

図 3 ネコの上オリーブ核の $\mathrm{a}$ : 外側核 (LSO) と b : 内側核 (MSO)のニューロンの強 拡大. ニューロンの樹状突起の形が異なる $(H R P$ 染色 $\times 200)$. 
側上オリーブ核へ到達する(図 4 ). 前者は興奮性, 後者 が抑制性である. 交叉性と非交叉性の神経線維は内側上 オリーブ核へ反対側から到達する。すなわち核の腹内側 と背外側へ達する。このようにしてすべてのニューロン は興奮性と抑制性の信号を受ける. 究極的には両側の上 オリーブ核内側核から聴皮質に至る情報量の差によって 方向感が生じる」

1930年, Békésy ${ }^{5)}$ は実験的研究から両耳干渉作用と, 時間一強さ取引 (time-intensity trade) の現象を報告し, この現象は上オリーブ核ですでに生じることが明らかに されたのである. 臨床的にも時間差によって生じた方向 感の偏りを強度差の調整によって正中に戻したり, 逆に 強度差によって生じた方向感の偏りを時間差の調整に よって正中に戻すことができる，また基礎的な研究では， 下丘や聴皮質の音源定位がそれぞれ両耳干渉作用を認め る報告が多いが，破壊実験で著しく両耳干渉作用が失わ れるのは上オリーブ核である，ただし上位レベルの障害 に関する臨床例の報告はもともと少ない。

上オリーブ核の役割については Osen') が1969年, 重 要な考光を提案した。すなわち，「外側核と内側核には anterior ventral cochlear nucleus (AVCN 前背側蝸牛神 経核)から投射されるが，外側核には小型の球状ニュー ロン，内側核には大さな球状ニューロンが起源となる。 この大小 2 種類のニューロンは分布が異なる.」その後 の研究でもこの違いが証明され，これらは別々の情報を 伝達すると考兄られるようになった。このようにして， その脳幹の聴覚伝導路の最初の段階で両耳聴のシステム
は平行してできている.内側核，外側核のニューロンは 上行し，下丘，内側膝状体，聴皮質でそれぞれの関連の 部位がある。図 5 にCasseday ら ${ }^{7}$ による模式図を示し た。上オリーブ核内側核が両耳からの信号を処理すると すると，図で示すように両耳の時間差があると左右とれ ぞれでAVCNの別々のニューロンが発火して収束する というものである.

\section{方向感検査の臨床応用の基礎}

両耳聴検査は，音像定位が脳内で生じることから，現 在のような $\mathrm{ABR}$ (聴性脳幹反応)や CT，MRIなどの診 断方法がない時代に，脳内の病巣診断を期待して研究が された．現在では，病巣診断よりも音源定位あるいは音 像定位の検査は, 認知機能検査として考光るのが良いと 思われる．特に聴覚情報というものが，時間因子 (temporal resolution) であることを身近に体験させる良い検 査であり，診断のみならず教育的に有用な検査である.

1960年代に竹尾 ${ }^{819)}$, 寺尾 ${ }^{10)}$, 切替ら ${ }^{11)}$, 設楽 ${ }^{12)}$ は, ITD (interaural time difference) 調整装置(図 6,7) 製作し，検査音の強度差を変光ることなく，時間差のみ を自由に変えることができるよらにし，方向感に拈忷る 時間差と強度差の役割を調べるとともに臨床応用を行っ た. 図6亿示すよらに，2つのマイクロフォンの位置の 距離を変えることで時間差を作っている．強度差を作る には，この装置を 2 台必要とする。この装置による研究 の成果を以下にまとめる。

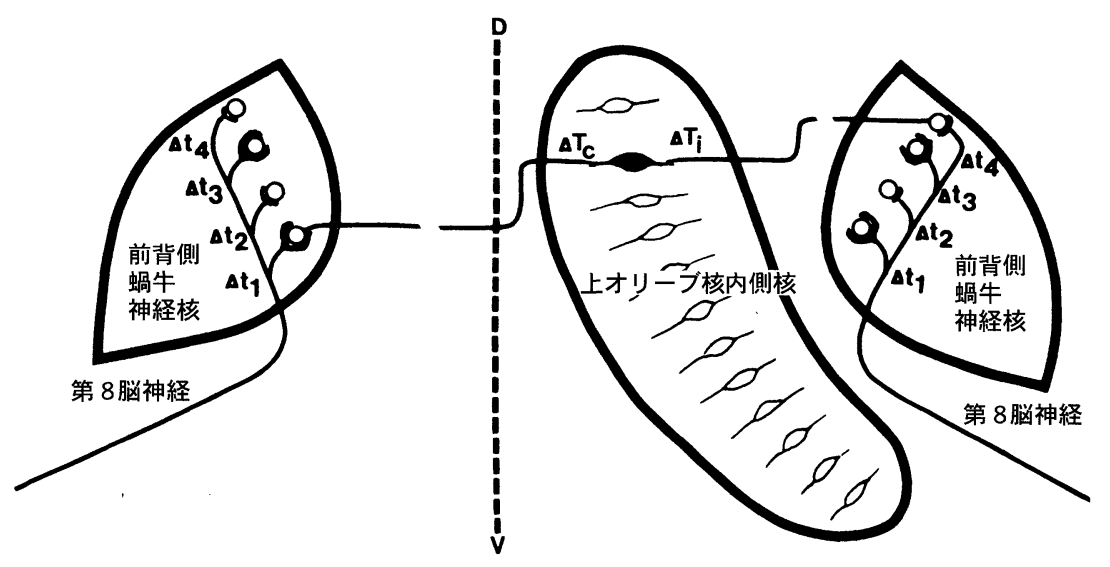

図 5 両耳から届いた信号は時間差があると同じ音源でも AVCN の別のニューロ ンが発火し, 同一のニューロンに収束するといら模式図 (Casseday JH, et al : 19877) より改変 


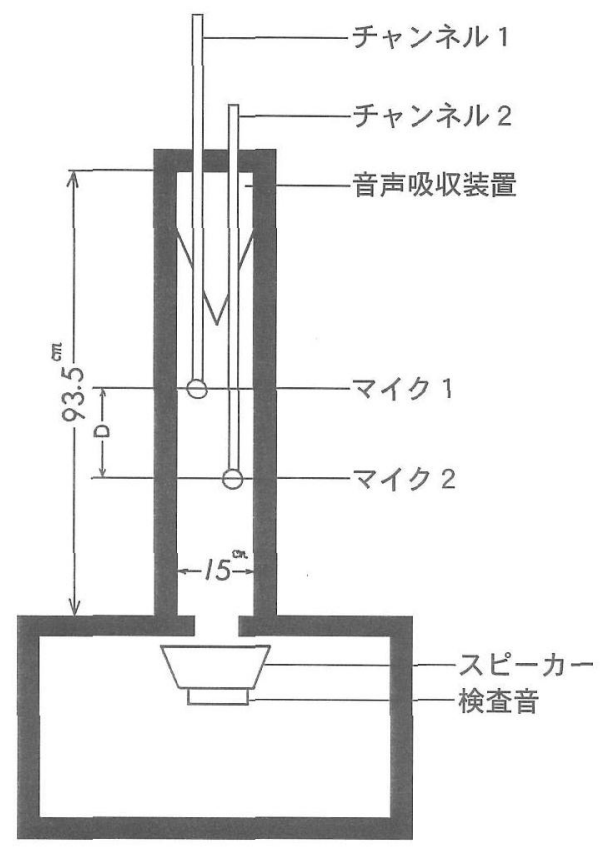

図 6 ITD 調整装置の図解 (切替一郎，他：196411)より改変）

\section{a . 基礎的事項899}

1.両耳に入る音の時間差によって生ずる方向感は楽 音, 語音, 騒音などの複雑音に対して敏感であるが, 純 音に対してはあ屯り明膫ではない。 $2000 \mathrm{~Hz}$ 以上の純音 では音像を結ばない。

2. 音の強さは $\mathrm{SL} 40 \mathrm{~dB}$ が最もよく, SL $20 \mathrm{~dB}, \mathrm{SL}$ $60 \mathrm{~dB}$ はこれより劣る。

3. 音の周波数は $600 \sim 850 \mathrm{~Hz}$ あたりが最も鋭敏で ある。

4. 切断音の場合には何らかの效果が生じて方向感は 鋭敏となる。

5。両耳間の時間差と強度差の関係は, centering technique と matching technique の2つの方法を組又合 わせて時間差 $(\mathrm{T})$ 対強度差 $(\mathrm{I})$ を比較すると

a）測定法のいかんを問わず 600 ～ $850 \mathrm{~Hz}$ バンド， イズに和いて最もゆるやかである。

b ）時間一強さ取引検査のグラフは centering technique では曲線となり, matching technique では直線と なった。

\section{b. 臨床的事項}

竹尾8) は臨床研究の目標を次のよらに述べている。「両 耳聴は単耳聴と異なり，両耳から上行する信号が中枢に

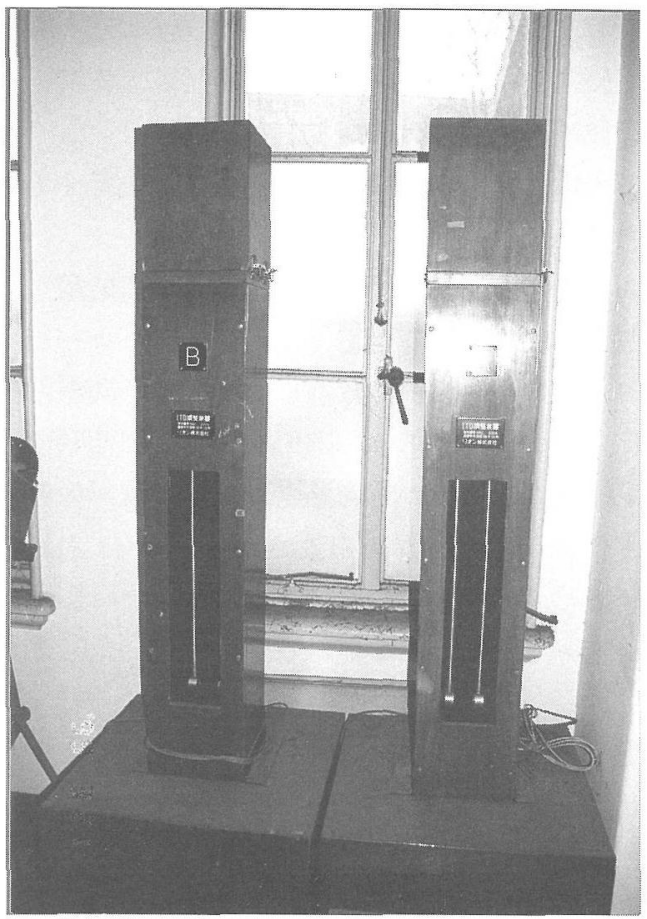

図 7 切替らの ITD 調整装置

形状から特墓と呼ばれた。東大耳鼻科資料室保存.

扣いて組み立てられて, 中枢固有の種々の複雑な現象を ひき起こす。単耳聴に比して両耳聴では音のピッチの升 別が容易となり，なた両耳語音明瞭度が上昇するなどる その 1 例である。したがって，これらの中枢性の現象を 指標にした検査法を確立すれば中枢性難聴を“感音難聴” のなかから取り出すことがでさるのではないかと考觉ら れる.」これが示すよらに中枢病变の評価を目標とした。 しかし, 当時は ABRゃ CT, MRI もなく, 被験者を得 ること自体が困難であったであらう。

切替らの開発した ITD 調整装置による臨床応用の成 果は，次のようである1112)。

1 . 伝音難聴者では正常者に比して音像成立機転に变 わりなく，患耳を補聴することによって正常者と同様の 音像を感知し得る。例外的に音像を結ばない例は，片側 に中耳炎後遺症があり，音が正円空より逆位相に入った ため音像が結ばなかったためであり留意が必要である。

2. 感音難聴では, 時間差が両側低音難聴, 頭部外傷, 高音難聴では異常であるが，平坦型家族性難聴や進行性 感音難聴では正常範囲であった。

3. 橋部のグリオーマの 1 例では正常. 


\section{4. 聴覚失認では異常.}

5. 脳血管障害で片麻痺の症例の半数で異常.

6. 頭部外傷例では $30 \%$ で異常.

7. 加龄が進むと時間差の弁別閾值が上昇する13).

新しい音像定位検査の方法と臨床応用

音源定位検査には無響室と多数のスピーカーを必要と するが，音像定位検査は故意汕両耳間の時間差と強度差 を変化させることがでさ，臨床検査として便利である。 音像定位検查としての方向感自動記録装置が佐藤恒正博 士ら ${ }^{14)} と よ り$ 開発され，市販されている(リオン株式会 社 TD-01)（図 8)。これは正中よりの音像の移動を自記 オージオメトリーの原理と組み合わせ自動化したもので ある。

防音室に执いてへッドホンを使用し，刺激音として $500 \mathrm{~Hz}$ のバンドノイズを与兄, さらに一側の出力を 1 $\mathrm{dB}$ ごとに微調整し, 被験者が音像を頭蓋正中に感じる ようにする.両耳時間差の検査については $2 \mu \mathrm{sec}$ ステッ プで連続的に変化する。この装置はスタートボタンを押 すと時間差 0 の状態から右の音が徐々飞早くなり, 被験 者が右に音像が移動したと自覚した瞬間に右のボタンを 押すと，瞬時に音の移動方向が逆転し音像を正中に戻す 方向に動くようにできている.ささらに正中を越光, 左に 音像が移動したと自覚した時点で左のボタンを押すと， また逆に音像が右へ移動するようにできている。このよ らにして検査を続けると, 両耳間の時間差音像定位が可 動であれば自記オージオグラムのような鋸歯状波が得ら れる(図 9)。本装置は最大 $2 \mathrm{msec}$ までの時間差を作る

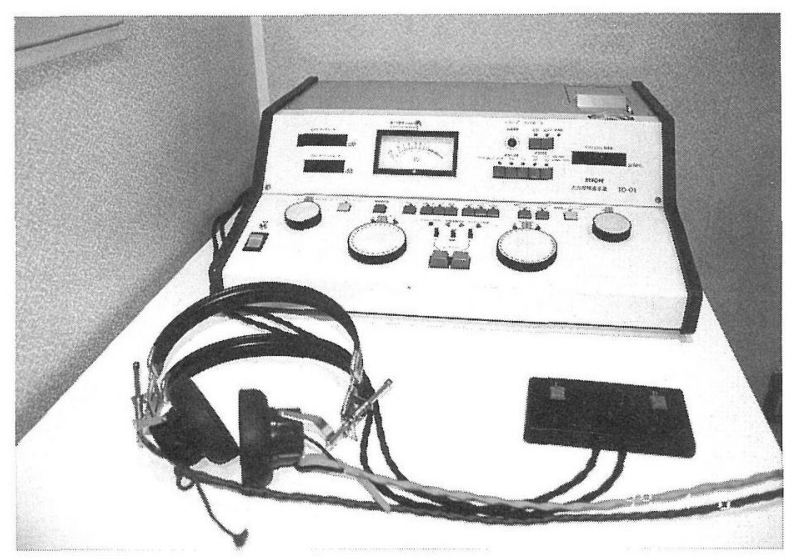

図 8 佐藤恒正博士とリオン社によって開発された方向感自動 記録装置 (TD-01)

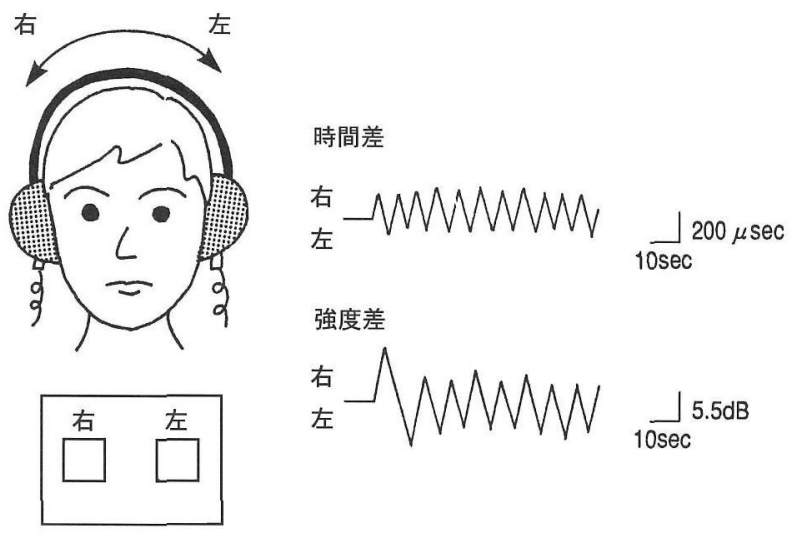

図 9 万向感検查

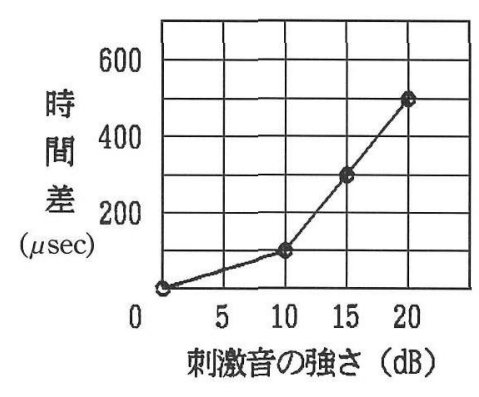

図10 新しい方向感検查による時間-強さ取引検査 時間差による音像偏倚をレベル差で正中に戻し，各時間 差でのポイントを線で結び傾斜で評価する。

ことができる。この鋸歯状波が安定して記録された部分 の連続した10個の振幅を測定し, その平均值を弁別閾値 としている. 一方, 両耳強度差音像定位検査では 1.25 $\mathrm{dB} /$ 秒の速度で右側刺激音圧を变化させて, 同様に記 録し評価する。以下, 両耳時間差音像移動弁別閾値 (interaural time difference discrimination) をITD, 両耳強 度差音像移動尣別閾值 (interaural intensity difference discrimination)をIID と略することにする.

時間一強さ取引検査も簡単に記録することができる(図 10）. 以下に本方法を用いた研究結果を解説する.

\section{発達と加齢}

a. 発 達

乳幼览の聴力検査で音源定位が指標として使われてい る. 乳児ですでに, 音源探索行動があり, 脳の発達とと もに条件付による音源定位反応が成立する，七トの脳の 
発生では生下時にはすでに髄鞘化が蝸牛神経では終了し ているが，脳幹の中継核は 1 歳過ぎまで髄䩗化がかかり 聴皮質聴放線は 2 歳過ぎまでかかる.

方向感検查は認知と判断の能力を必要とするため, 正 確な検査は純音聴力検査と同様に 4 歳以降でないと可能 とならない，Kaga'15) は，TD-01 を用いて調べ時間差の 発達には左右差はなく，成長とともに閾值は低下するが 5 歳では 20 歳代の 2 倍の閾值になっている(図11). しか し, 音圧差はバラッキが多いが，平均值でみる限り間值 は成長と無関係であることを明らかにした。このことは，

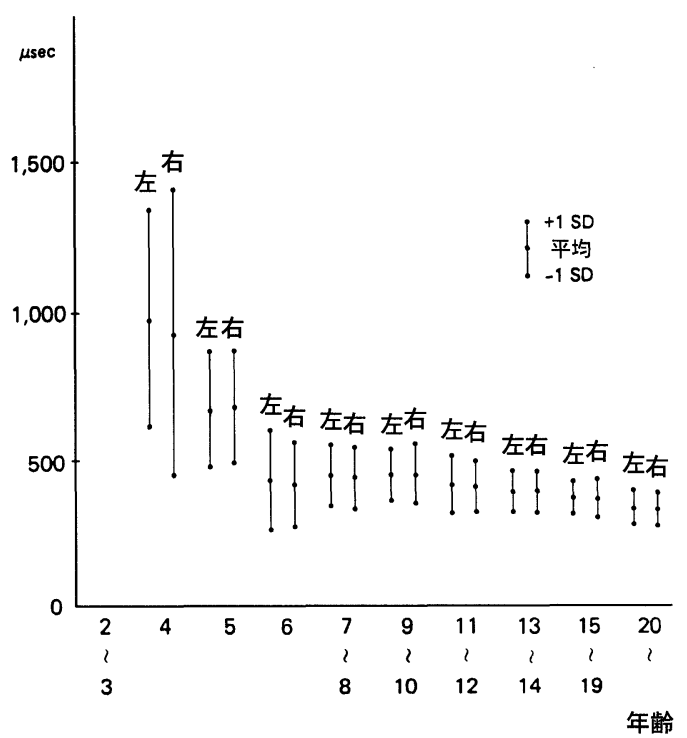

図11 小児の発達と ITD の変化 (Kaga M : 1992 ${ }^{15)}$ ๖改変)
純音聴力検査の閾值検査で成人と同様の正常閾値を示す ことと同様であろう．ピッチの弁別のように時間因子が 中心の音の情報処理は単耳聴でも両耳聴でも発達ととも に并別閾值が低下寸ることを示唆している. 逆に方向感 検査は, 脳神経疾患の音情報関する発達検査としても 可能性のあることを示唆している.

b. 加 齢

Kirikae ら ${ }^{13)}$ は1964年，加齢による影響を著しく受け るものの一つが方向感の時間差であると報告し，60歳を 過ぎると次第に閾值が高くなるがこの理由として, 脳幹 から聴皮質にかけての加齢による神経系の変化を挙げ, 神経線維の数の減少を疑っている.

TD-01 を用いた高齢者の研究では，久松ら ${ }^{16)} も ， 500$ $\mathrm{Hz}$ バンドノイズでは65歳以上の群では, 若龄者よりも 閾值が高く，加齢による後迷路障害の影響であるという． しかし, 著者ら ${ }^{17)}$ は現在の聴覚機能検査を組み合わせ, 高齢者を老年医学会の分類，すなわち老齢前期 $(65 \sim 74$ 歳), 老歯後期 (75 84歳), 超高齢期 (85歳以上) 飞分け $\tau$, 純音聴力検査, 語音聴力検査, DPOAE, ABR, トー クンテストで内耳から聴皮質の機能検査に加兄, 方向感 検査を行ってきた。その結果, 加齢による難聴は生理的 な加齢では後迷路性の障害よりも，内耳性の難聴の影響 が中心であるという見解をもつに至った。図12 筆者 ら 17) の高齢者の方向感検查の予報的な結果を示す.こ れをみてもわかる通り，高路になっても正常範囲の結果 を示するのが少なくない，単に平均值をとれば閾值は高 くなるが，それをまとめて高齢による後迷路障害という
《60歳代》

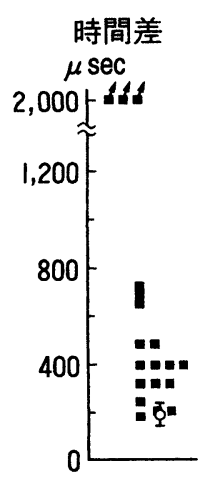

《70歳代》

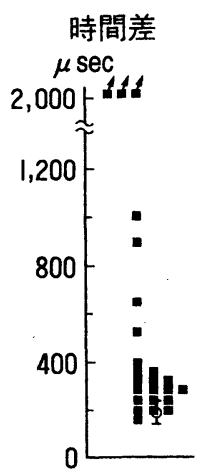

\section{《80歳代》}

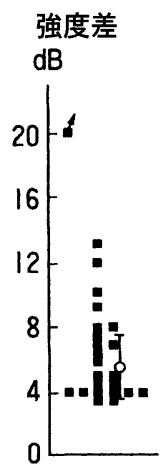

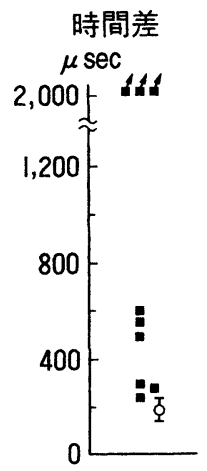

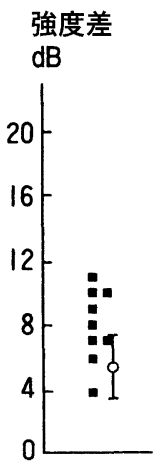

図12 高齢者の方向感検査の成績, 時間差, 強度差とも正常な例が少なくない.

口は症例 1 例を示してある. ○は平均值を示す.（加我君孝，他：199917）より転載） 
ことはできない.100歳の老人の脳の研究で, 水谷 ${ }^{18)}$ 最後まで神経病理学的に, 視覚系や聴覚系の上らな特殊 感覚系であるという，著者は，真に脳幹の聴覚伝導路や 大脳の聴皮質や聴放線の障害例について研究を行ったが， 高㱓による難聴とは全く異なる病態像であった，高㱓に なるにつれ，検查を理解させるのに時間がかかり，方向 感検査のようと認知や集中力と敏しょらな運動能力を要 する検査では, むしろ聴覚以外のファクターが結果に反 映していることもあり得るので注意が必要である。高齢 による難聴の中心は後迷路障害といらのは正しいとはい 完ない。

\section{聴力障害}

両耳聴は実際の臨床の場では, 先天性難聴の幼小児, 呿よび後天性難聴の成人に対しての両耳補聴器装用が, 現実的な課題となっている。前者も後者も, 音源定位, 音の移動知覚, 語音知覚の明膫度の向上, カクテルパー ティ効果を可能にすることが期待されている．ただし先 天性の場合は，片耳装用だけで対側耳を使わないでいる と, 成長が進んでから使わない側に補聴器装用を行って も効果が乏しい。すなわち脳の可塑性汇臨界期があるた め初めから両耳装用が望ましい。このような臨床的な課 題の理解のために，末梢性難聴では方向感はどのような 影響を受忊るか検討する。

武田 ${ }^{19}$ は伝音難聴, 感音難聴および補聴器装用者に 対してTD-01を用いて調べ報告しているので以下に紹 介をする。

I . 伝音難聴・混合難聴

a . 片側性伝音難聴, 混合難聴例(患側 $500 \mathrm{~Hz}$ の気 導聴力の平均 $49.2 \mathrm{~dB}$, 骨導聴力の平均 $22.2 \mathrm{~dB}$ ). 閾値 の軽度上昇例が時間羑で $39 \%$, 強度差で $11 \%$, 骨導聴力 レベルが $25 \mathrm{~dB}$ 以上の混合難聴では閾値が上昇する.

b . 両側性伝音難聴拉よび混合難聴例 (気導聴力の平 均右 $59.1 \mathrm{~dB}$, 左 $59.4 \mathrm{~dB}$, 骨導聴力の平均は右 $21.6 \mathrm{~dB}$, 左 $20.9 \mathrm{~dB}$ )。時間差の閾値の軽度上昇例か $31 \%$, 強度 差では $6 \%$ であった。

このよらに伝音難聴が主の症例でも時間差の陽性率が $30 \%$ 以上といらのは不思議な感じがするが Hausler ら 20 , Zurek $^{211}$ はレシーバーからの骨導音の関与を指摘し，そ の機序について「レシーバーからの刺激音が頭蓋骨を介 して内耳へ伝わった場合, 両側の内耳は独立した状態で はなくなり, 本来の外耳, 中耳伝音系を介した気導音と
骨導音は内耳に扔いて干渉し音像定位機能を低下させ る」と解説している.

II. 感音難聴

a) 片側性感音難聴 (500 $\mathrm{Hz}$ の平均聴力レベルが 28 $\mathrm{dB})$. 時間差で弁別閾值の上昇を認めたのは18\%で，そ のうち軽度のものとスケールアウトが半々であった．強 度差の閾值上昇を示したのは14\%で，いずれも軽度の閾 値の上昇を示したにすぎない。

b ) 両側性感音難聴 $(500 \mathrm{~Hz}$ の平均聴力レベルは右 $43 \mathrm{~dB}$, 左 $50.4 \mathrm{~dB})$. 時間差の弁別閾値の上昇を示した

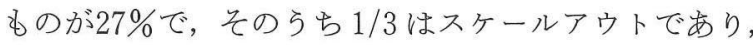

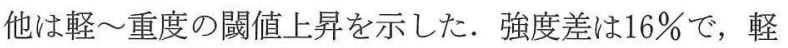
〜中等度の閾値の上昇示した。

感音難㯖の両耳機能検查では時間差が異常をきたす率 の高いことが報告されている22233.

メニエール病では強度差の異常率が高く, これは蝸牛 の補充現象のためであるという，感音難聴の異常例は， 他に，神経性難聴の合併例や，検査の理解が難しい例な ぞが考光られ，後迷路障害の関与も否定はできないが， 簡単に中枢障害説に帰結することには慎重であるべきで あろう.

III. 補聴器装用下の音像定位

補聴器装用下の検査のために, 耳掛型補聴器をすっぽ り覆うよらなレシーバーを新たに開発して検査を行った (図13).

先天性高度感音難聴で10歳の症例のオージオグラムを 図14k示す. 平均聴力は右 $84 \mathrm{~dB}$, 左 $88 \mathrm{~dB}$ であるが, 時間差も強度差の閾值も正常範囲内であった。

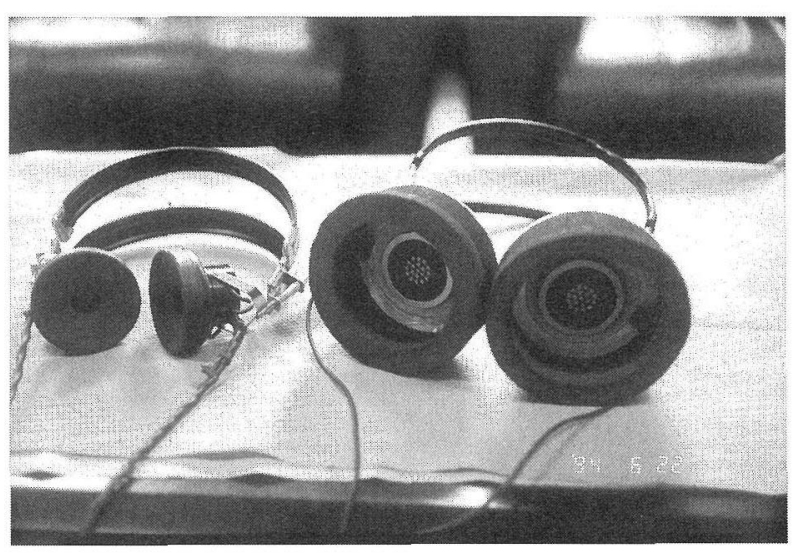

図13 耳掛型補聴器装用下の方向感検査のために作製した，レ シーバー(左). 右は通常の検查のためのレシーバー. 


\section{a ）先天性両側高度感音難聴児}

対象はろ 学校の生徒15例, 平均年齢14歳, 平均聴力 は 4 分法で右 $103.1 \mathrm{~dB}$, 左 $100.7 \mathrm{~dB}, 500 \mathrm{~Hz}$ について は右が $80 \mathrm{~dB}$, 左が $90.7 \mathrm{~dB}$ であった. 全例が耳掛型補 聴器を両耳に装用していた。時間差, 強度差の両方とも 音像移動の弁別も不可が $47 \%$, 強度差が不可で音圧差が 可能であったものが33\%, 共に可能であったのは20\%で あった。このように時間差の結果が悪い例の多いことは, ダイナミックレンジが狭いこと, 周波数分析能, 時間分 解能の高度障害によって, 補聴器による増幅にかかわら ず, スケールアウトになったのであろう。だからといっ て補聴器の両耳装用が意味がないといらわけではない。 両耳装用の方が聴覚情報を抽出する能力が向上するから である。

\section{b. 先天性両側外耳道閉鎖症例}

先天性両側外耳道閉鎖症例に対し, 現在のところ 1 個 の骨導補聴器がフィッティングされている. 1 台の骨導 補聴器で両側の内耳が刺激されるからである. 骨導補聴 器 2 台を使用することについては理論的に両耳聴が成立 しないので意味がないという考えもある。しかし，骨導 端子を頭蓋骨のさまざまな位置に特くと, その位置が同
定できる、しかしこれは振動の位置覚ではない，著者ら は両側の骨導端子を乳突部に置いて, 方向感検査を行っ たところ，時間差も強度差も成立することがわかった ${ }^{24)}$ (図15). 両耳骨導 ABR でも両耳の干渉成分が出現する ことから, 骨導に㧧いても両耳聴は存在するものと考光 られる25).

\section{c . 後天性両側感音難聴}

対象は22例, 4 分法による平均聴力は右が $57.4 \mathrm{~dB}$, 左が $53.8 \mathrm{~dB}, 500 \mathrm{~Hz}$ の聴力は右が $56.8 \mathrm{~dB}$, 左が 50.9 dB19) であった.

両耳装用者に招いては補聴器の非装用時, 時間差では $32.3 \%$ ，強度差では20\%で閾值の上昇を認めた。ところ が補聴器を両耳に装用させて方向感検査を行うと時間 差では $80 \%$, 強度差では $7 \%$ で閾值の上昇を認めた。こ の原因として補聴器により増強された刺激音の周波数特 性の影響や時間因子の左右差やリクルートメント現象の 影響などが考学られる. しかし強度差がよく保たれるこ とは，低周波領域の補聴に良い効果があると思われる。 Gelfand ${ }^{26)}$ は成人で片耳に補聴器を 2 年以内使用し, そ の後の 2 年以内に両耳補聴にすると両耳効果があるが, $5 \sim 6$ 年片耳補聴器装用した人がその後 $5 \sim 6$ 年両耳装
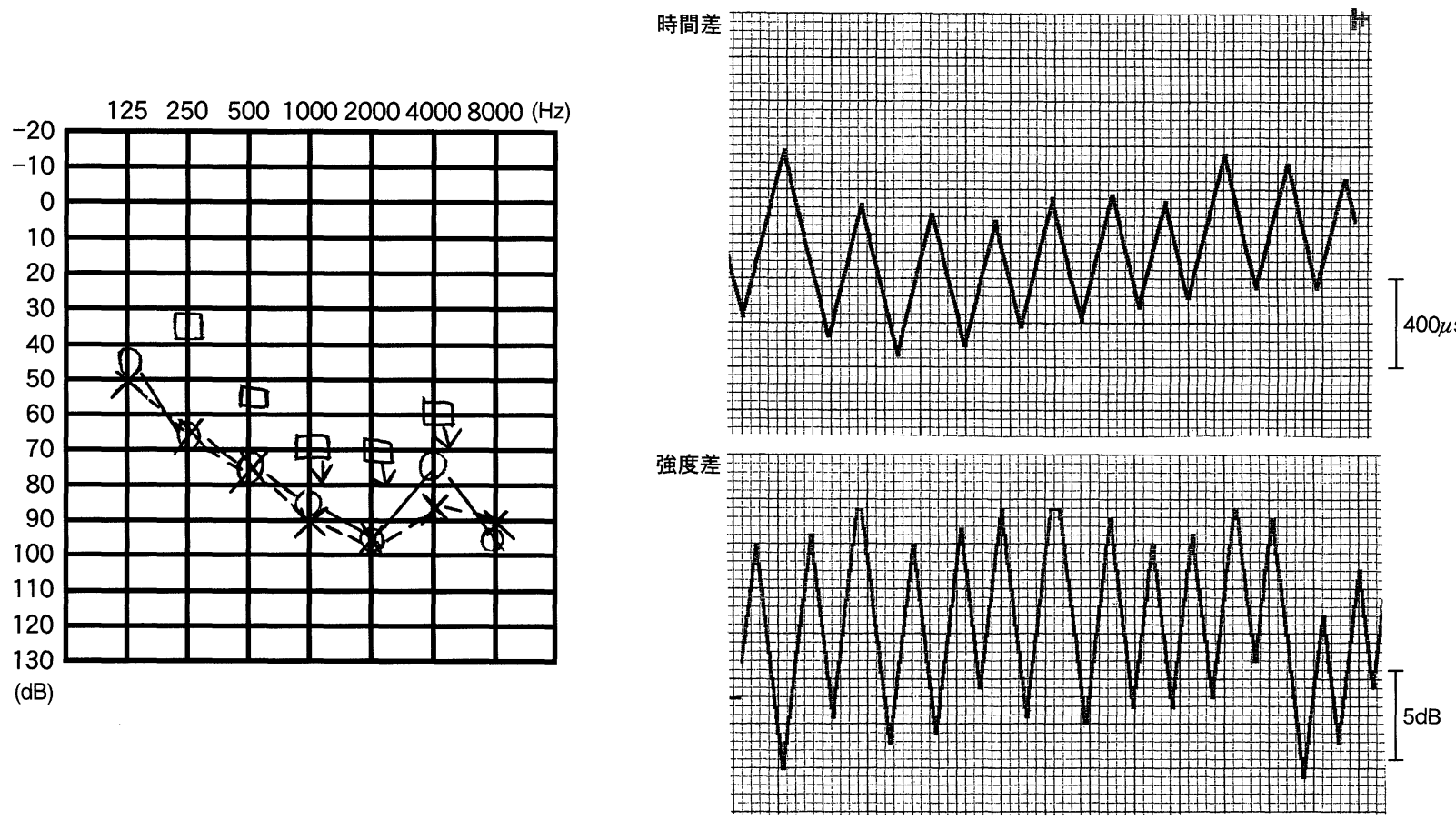

図14 高度感音難聴小児(10歳)症例のオージオグラム (左) と補聴下の ITD と IID 両検査 (右) とも軽度域值が上昇している. 
1. 強度差

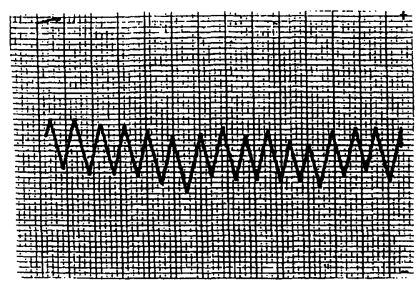

$1 \mathrm{~mm}=1 \mathrm{~dB}$
2, 時間差

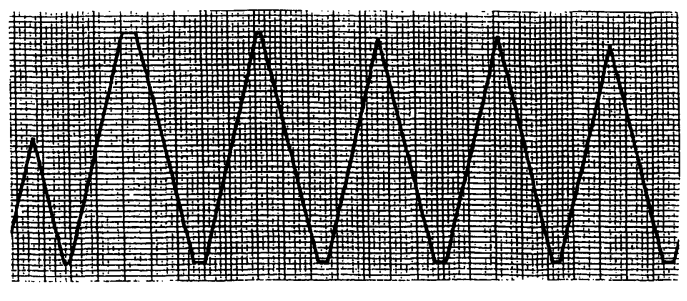

$1 \mathrm{~mm}=40 \mu \mathrm{sec}$

両耳カナル型補聴器装用下の方向感自動検査の記録を示す. 音圧差の振幅は小さ いが，時間差の振幅は著しく大きくなっている.

a

1. 強度差

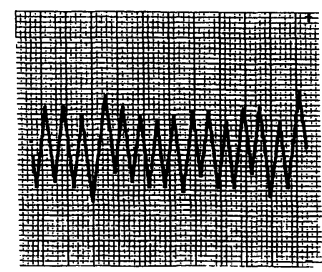

$1 \mathrm{~mm}=0.5 \mathrm{~dB}$
2. 時間差

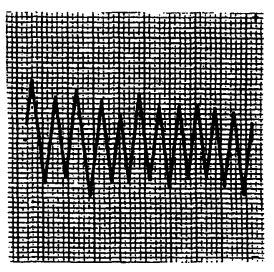

$1 \mathrm{~mm}=20 \mu \mathrm{sec}$

両側骨導受話器装用下の方向感自動検查記録. 強度差, 時間差ともに振幅は小さいことがわかる.

b

図15 先天性外耳道閉鎖症例

両側とも外耳道が形成されている(岡村るみ, 他 : 199725) より転載).

用にしても効果がないといら。切替ら ${ }^{27)}$ は両耳用補聴 器は単耳用に比べきわめて方向感は良好であるが頭部の 陰影効果が関与すると強調している.

\section{聴神経障害}

蝸牛神経の役割は音情報の伝送である.片側性聴神経 腫瘍では時間差の陽性率は佐藤ら 28$)$ にると $93 \%$, 山 田ら ${ }^{29)}$ は $100 \%$, 武田ら ${ }^{30)}$ は $85 \%$, 強度差の陽性率は山 田らによると $85 \%$, 武田らは40\%と報告している(図16). 陰性例は腫瘍径の小さいものが多い, 両側の蝸牛神経障 害には聴神経腫瘍挹よび auditory nerve disease ${ }^{31}$, auditory neuropathy ${ }^{32}$ ), 本態性後迷路障害 (この 2 つの名は 報告者は違らが同一の病態と考兄られる) は, 時間差る 強度差ともに陽性である。

佐藤ら ${ }^{28)}$ は「聴神経腫瘍例では少なくとも ABRのI 波のみは残存する事実より聴神経幹に拈ける伝達障害に
より，I波以降の同期的発火が不可能となるものである ら。また，方向感成立の際には患側神経幹に括ける情報 伝送時にインパルス群の遅延, 消失による同期性の変化, 消失が起こり, 対側耳の対応インパルス群との間の時間 因子の正確な保持が不可能となり，上オリーブ核群にお ける正常の整合ができなくなるためと思われる」と述べ ている.両側の蝸牛神経障害では同じ理由で時間因子ば かりか強度因子まで正確な保持が不可能になるのである う。では蝸牛神経がぞの程度障害されると正確な保持が 困難になるのであろらか. Schuknecht ら ${ }^{33)}$ は聴神経幹 の線維自体の持つ圥長性のために $20 \%$ 程度が残存してい れば，オージオグラムの低下はみられないといら．万向 感検査ではオージオグラムが正常でも方向感検査の時間 差が悪化する例の多いことから，少なくとも20\%以上の 蝸牛神経の残存が必要と思われる。すなわち, 佐藤28) のいらように「腫瘍により正常の機能を保有する線維数 


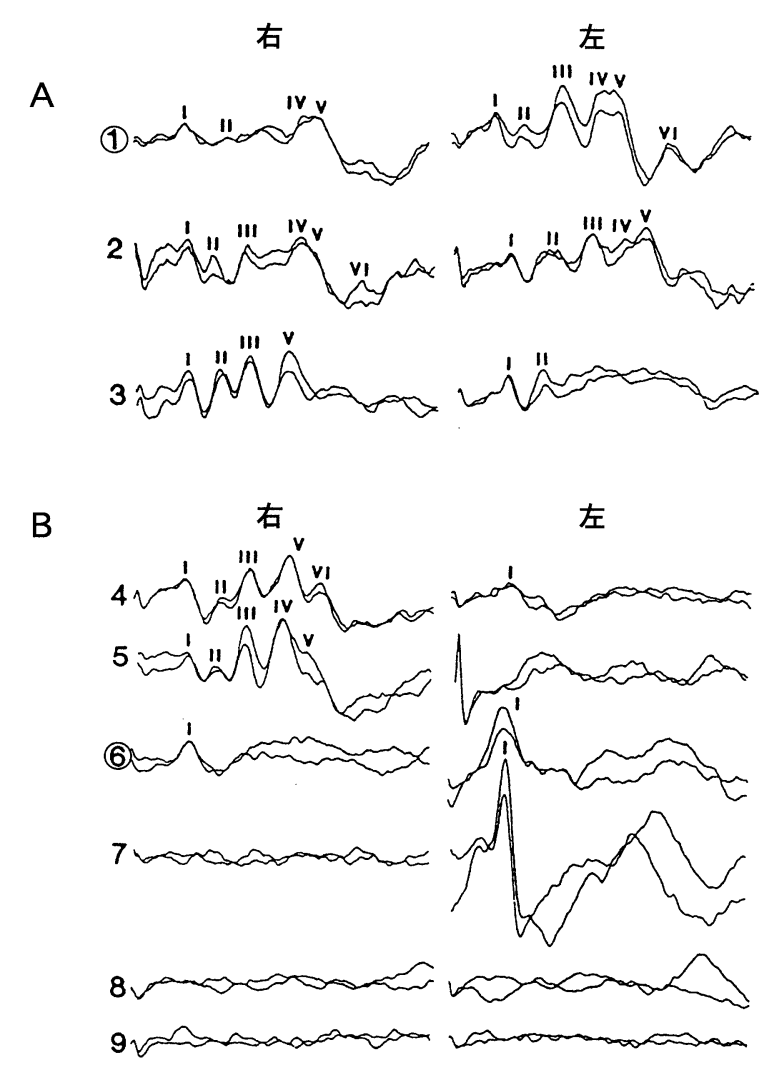

A

\section{症例 1}

\section{時間差}

$$
\bigwedge \aleph_{10300}^{2004800}
$$

強度差

$$
\text { WWMMM }
$$

B

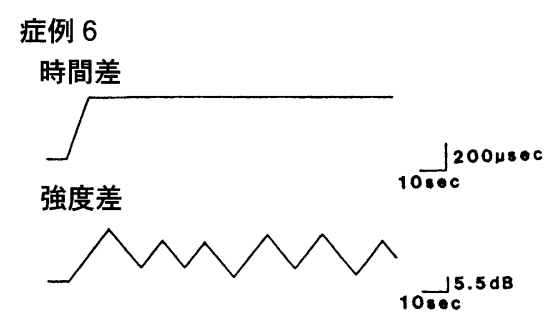

図16 聴神経喱瘍と ABR と方向感 $(A ：$ 方向感正常, $B$ : 方向感異常)

症例 1 は右 AT, 症例 6 は両側 AT. 前者は良好であるが後者は時間差は域値上昇, 強度 差は良好 (山田勝士, 他 : 199129) 上り改変).

の減少により, 純音閾値に関する情報は伝達できるが, 閾值上の時間因子の伝送障害が早期に発生するものであ らら」と考光られる。

\section{脳幹障害}

脳幹障害の正確な部位診断は ABR, MRI の臨床応用 によって初めて可能となった，それ以前は眼球運動系の 検査が主な診断の手がかりであったが，ABR は脳幹の
聴覚伝導路そのものに由来していることから, 正確な脳 幹聴覚伝導路障害部位の聴覚心理研究が可能となった。 山田ら ${ }^{29)}$ は図17亿示すような $\mathrm{ABR}$ 異常波形を示す症例 では, 時間差の陽性率は $100 \%$, 乙かも強度差も軽〜中 等度の異常を示すという. 以上の例は脳幹梗塞と脳幹腫 瘍例であるが，多発性硬化症を対象とした研究があり， Van Der Poel ら ${ }^{34)}$ は, 少なくとも片側の ABR のIII波 に障害があれば時間差音像定位弁別閾值が著明に上昇す 
ると報告している．Levine ら ${ }^{35336)}$ は，20〜1000 Hzの low-pass filtered noise burst と $4 \sim 20 \mathrm{kHz} の$ high-pass filtered noise burst の 2 種類の音刺激を用い, 時間差と 強度差について調べABR と比較している．時間差の陽 性率が強度差より著しく陽性率が高く(70\%：11\%), low-pass noise の方が high-pass noise より顕著である. 亚波が低振幅であると両方の音刺激とも時間差の異常を 認めるが吕波の潜時の延長だけでは high-pass noise の みが異常, 片側のV波の振幅が異常であると high-pass noise の久が異常で，両側のV波の振幅が異常であると， low-pass も high-pass も異常を示したと報告している37). $\mathrm{ABR}$ のIII波は上オリーブ核に由来することが証明さ れて括り，上オリーブ核を中心に核性，核下性，核上性 の3つに分類をするのはどらであらうか．四波が低下あ るいは消失し I，II波のみの場合が核性，I 波のみが核 下性，I，II，正波のみあるいは $\mathrm{N} ， \mathrm{~V}$ 波が低振幅であれ ば核上性の脳幹聴覚伝導路の障害といってょいと考兄
られる. 図17にそれぞれのタイプの ABR が示されてい るが，どのタイプでも時間差も強度差も異常である. Masterton ら ${ }^{38)}$ は聴覚伝導路内で上オリーブ核の末梢 側の台形体核と中枢側の毛側毛帯核をそれぞれ部分破壊 したネコの方向感を比較した．台形体核の破壊では時間 差は異常となるが外側毛帯核の破壊では影響がないとい ら。ヒトのI，II，且波のみ，すなわち核上性に相当す る.

Levine ら ${ }^{35) 36)}$ が指摘するように方向感検查の ABR との比較研究はこれまでの動物実験を参考にすると, ヒ トの聴覚伝導路の情報処理の理解に進歩をもたらし, 今 後の研究の基礎となるであらら.

\section{聴皮質障害}

聴皮質の機能は周波数の tonotopicity，すなわち周波 数, ON-OFF, 音のパターン, さらに音圧の変化の弁別 などで，このような機能により言葉，音楽，環境音が区

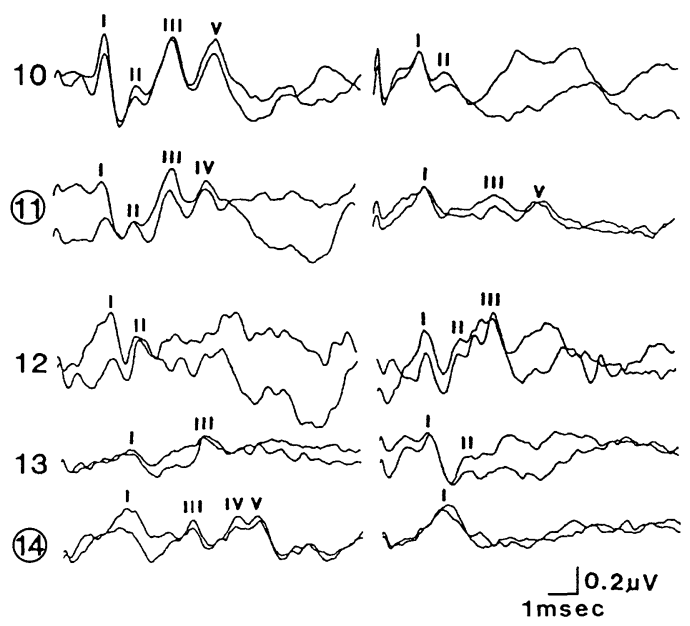

症例 11

時間差

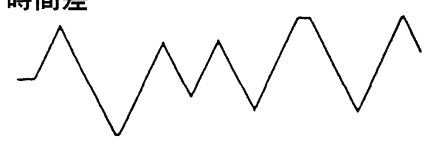

強度差

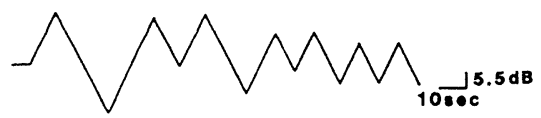

症例 14

時間差

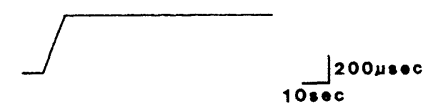

強度差

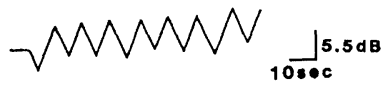

図17 脳幹障害と $\mathrm{ABR}$ と方向感 症例11は左脳幹梗塞, 症例14は小脳・脳幹腫瘍術後. 時間差は両者とも悪い. (山田勝士, 他 : 199129) より改変) 
別され認知される．分析機能はより鋭敏になるが，学習 や記憶までが含まれるかは明らかではない，聴皮質や聴 放線の障害は, 中大脑動脈やその分枝の破綻による出血 や閉塞によって生じる. 頻度の多いのは被殼出血で, 出 血が吸收されて初めて，障害が被殼の近傍を走る聴放線 にも及んでいることがわかる．乙かし機能的には，片側 性の障害である限り自覚は乏しく, あえて聞いてみると 障害と反対側の聴き取りが悪く膜が張ったようであると 答える. 純音聴力検査では異常はなく, 語音聴力検査で は, 障害と反対側の最高明瞭度が低下し, 左右差がある のでわかる，失語はない，両側の聴皮質あるいは聴放線 が障害されると，皮質襲あるいは聴覚失認といい，言葉， 音楽, 環境音の汪とんどすべての認知が困難となる。た だし，音としては聴こ党，その強弱もわかる点が内耳性 の聾と異なる点である。では音の強弱はどこで認知され るか. 細かな強弱は聴皮質で認知されると思われるが, 大まかな強弱は現在, 脳のどの部位で認知されるか不明 である。

\section{1. 片側聴皮質障害}

著者らは12例の左聴皮質障害例について調べ39)，代表 的な 3 症例の方向感検查のデータそのものを図18-a, b，c飞示した。症例 1 （a ）は左右方向に対照的である が症例 8 (b) は時間とともに右へ偏倚している. 症例 2 （c）は左へ偏倚しているが, 強度差の方は偏倚がない。 12 例とも左の損傷例であるが，平均值が $418 \mu$ ses でュ ントロールに比べ，著しく高く有意である．このことは 片側の障害例では，時間分解能が軽〜中等度低下してい ることを示唆している.

両耳強度差音像定位検査は11例に行うことができたが， 平均値が $9.46 \mathrm{~dB}$ で, コントロールの平均值が $5.5 \mathrm{~dB}$ で, 約 2 倍で, きわめて有意 $(\mathrm{t}=4.78, \mathrm{p}<0.01)$ である. 音の強度差についても聴皮質が関与していることを示唆 している。

音源定位法を用いた過去の研究報告によると，片側の 側頭葉損傷では，損傷と反対側の空間での音源定位が低 下するといらもの 40441$)$, 同側あるいは反対側への偏

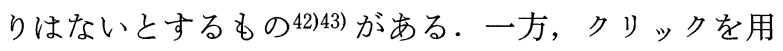
いた音源移動法では Walsh'44) とよると片側大脳半球損 傷例では時間差を区別できるが闇值は上昇するとし，片 側の聴皮質を除去しても両耳時間差の区別する力は失わ れないとし，われわれの研究結果39) と同様である.す なわち左右の聴皮質とも time cueを分析できることが

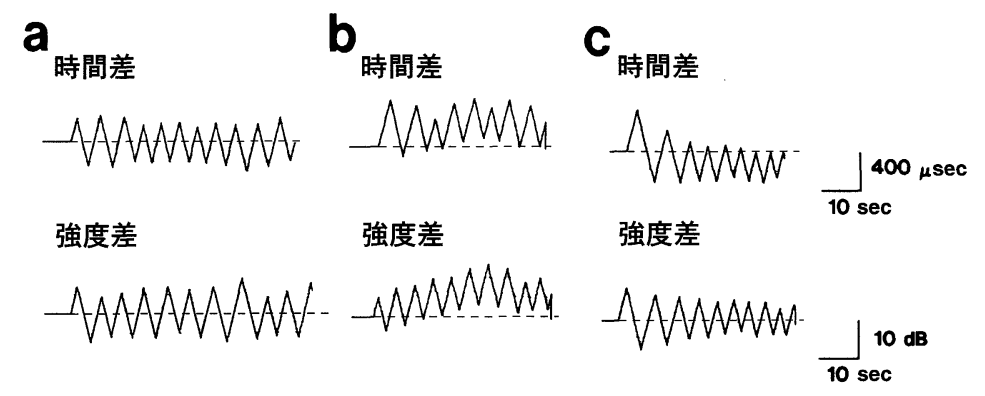

d

時間差 時間差
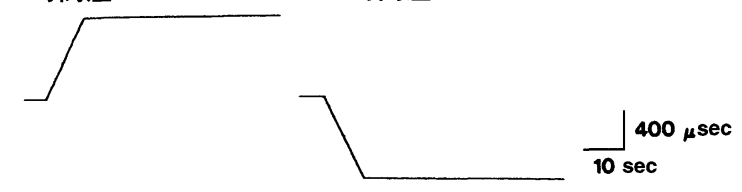

強度差

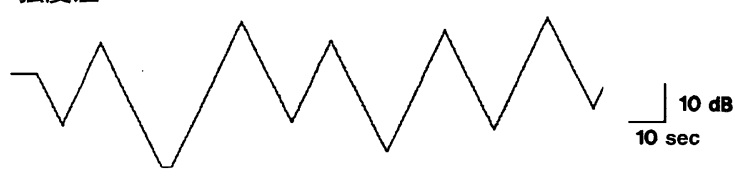

図18 a . 左聴皮質障害(症例 1), b. 左聴皮質障害(症例 8), c . 左聴放線障害(症例 2), d . 両側聴皮質障害(症例15) (Yamada K, et al : 199639) より改変) 
わかる．ともかく片側の聴皮質が必要である. 強度差の 閾值については，Bisiach ら ${ }^{45)}$ は, 純音の両耳強度差音 像定位検査を片側大脳半球損傷に対して行い, 左右のい ずれの半球障害でも低下すると報告している．著者らの 結果も同様である.

\section{2 . 両側聴皮質障害}

両側の損傷例では音は聴こ党るがその弁別はできない 状態になる. 代表的な 1 例の方向感検査のデータそのも のを図18-d 亿示した．強度差の閾値は高く，記録可能 で，一方時間差の閾値は并別できなかった。他の 2 例も 時間差の弁別は全くできなかった，1例では閾值が上昇 していた.

Jerger らは両側の側頭葉損傷の 2 例46647) に対して自 由音場の音源定位検査を行い，1例は音源定位能力が低 下していたが，もう1例はそうではなかったため音源定 位能力は側頭葉損傷と必ずしも関係ないと結論づけた。 しかし，両側例では音源定位能力が低下するといら報告 が多い。このよらに矛盾した報告が多いのは, 病巣の大 きさ, 位置, 病因, 重症度, 年齢検査方法などが異なる ためであろう。

時間差は全く認知できない，しかし強度差の閾值が高 くなっているが強度差が両側聴皮質損傷でも可能である ことは, 恐らく内側膝状体 (MGB) から, 聴皮質以外の 知覚中枢へ投射す伝導路が強度差成立にも関与している と考学られる.MGB は時間差と強度差の信号処理がな される核であり，聴放線は MGB のニューロンであるか らである。

\section{その他の方向感と関連のある問題}

a . 片側難聴者の方向感

レシーバー法の方向感検査の弱点に片側難聴者では検 查ができないことが挙げられる。両耳聴の特徵に音源定 位, 音の移動感, カクテルパーティ効果が挙げられるが, 実は片側難聴者でも音源定位は可能である，それはなぜ であろらか。

及川 48) は移動スピーカー法を用いて片側の難聴と片 側の襲症例を調べ，両群とも方向定位能力が劣り患側方 向が悪いが，先天性の片側聾では後天性よりも良好であ るといら，同様飞片側壟では悪いとする報告が多 (49) 51). この研究では頭を固定している. 恐らく，も し頭部を固定しなければ，頭部を動かして音源を探索し， 音源を同定できるものと思われる。これを明らかにする
には，頭部の位置の動きを感受するセンサーを用いて記 録し，音源の位置との差を同時に調べる装置を用いれば 可能となるであろう.

\section{b ．視覚障害者の方向感}

先天盲を初めとする視覚障害者では, 純音聴力検査や 語音聴力検查で, 晴眼者より良いということはないが音 源定位能力は優れているといら報告がある52)。TD-01を 用いて矢部ら ${ }^{53)}$ は先天性重度視覚障害, 後天性重度視 覚障害, 弱視の 3 群に分けて調べたところ, 先天性, 後 天性にかかわらず, 重度視覚障害群は対象群に比較し有 意に升別閾值が低かったが弱視群とは差がなかったとい $\zeta$.

Röder ら ${ }^{54)}$ は, 盲人や視覚を奪った動物では聴覚に よる弁別能力が高くなるといらこれまでの研究について 補償的知覚強化現象の性質や一般性がないことを批判し， 正面特よび側方からの音に対する空間的弁別能について 調べ，全盲者では側方からの音に対してのみ高い音源定 位能力を見い出し, 全盲者での皮質処理領域の変化は, 側方からの音に対して定位能力をあげるような再編成で あることを示唆した。

c ．バイノーラルステレオ

スピーカでの再生は空間で音が混じりあって左右の耳 に届くが，ヘッドフォンでは直接届く. 左右の耳のすぐ そばに音源があるように感じるへッドフォンの特異な聴 こえ方 (binaural effect)を自然なものにしょうとするの

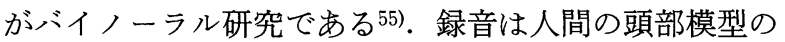
耳にあたるところに 2 本のマイクをセットして録音する。 この方式で録音しへッドフォンで聴くと音が頭の外に広 がって立体感のある音の再生ができる，時間差，強度差， 位相差が管理されるからである．頭部模型拉よびバイ ノーラルステレオの CD P LP は市販されている。まさ に仮想音響空間を体験できる，バイノーラルの正式な記 録の最初は1900年のパリ博覧会であるという．現在は， バーチャルリアリティブームに乗って，各種のステレオ 再生方式が市販のオーディオ，テレビなどに組み込まれ ているが，バイノーラルステレオほどリアルなるのはな (56).

\section{d. 哺乳類の方向感}

動物の方向感検查は難しい，スピーカ法による音源定 位の条件付けを行って研究することになる. Heffner ら57) は，多くの種類の哺乳動物を対象飞調べ，それぞ れの音源定位の閾值を角度で示し，そのマップを作成し 


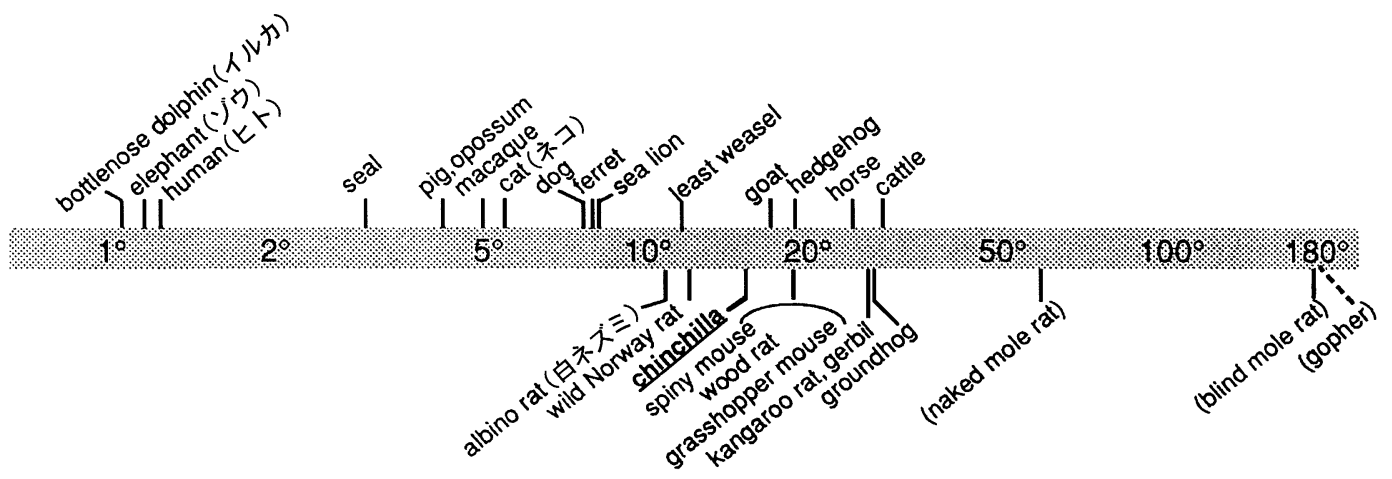

図19 哺乳類の音源定位の閾値

$100 \mathrm{msec}$ あるいは $400 \mathrm{msec}$ のノイズバーストによる反応 (Heffner RS, et al : 199456) より改変).

た、イルカ，ゾウ，ヒトは $1^{\circ}$ 程度の閾值であるが実験 によく使われる白ネズミは $10^{\circ}$ と鈍感であることが示 されている．ネコでも $5^{\circ}$ と割合閾值の高いことがわか る(図19).

\section{おわりに}

方向感検査のうち両耳時間差は鋭敏なパラメーターで あり, 聴覚神経系の蝸牛神経より聴皮質に至る中枢伝導 のどの部位の障害でも弁別閾值が増大する．このことは， 聴覚に括いては “時間”の因子が重大なことを示してい る.ただし末梢障害でも，特に蝸牛の障害でも時間差の 悪い例がある。これは補聴器によって聴力の損失分を 補っても改善しないのは, 蝸牛障害によっても障害が重 いと時間分解能が障害され得ること, さらに難聴といら 状態がある一定期間以上特かれると感覚遮断状態に沶か れたために脳の可塑性が低下したことなどが原因である 可能性も否定できない，逆にこの事実は，方向感は脳の 可塑性の評価の一つに利用でき得る可能性を示唆してい る。

一方，両耳強度差は臨床の評価に用いられることが少 ないが，時間差の閾值が高いときに被験者が本検査法に 習熟していないか疑われることもあり実施して扣きたい。 中枢障害で時間差が悪いときに，強度差が良い例が少な くないことは，認知の機序が異なることを示唆している. 両側聴皮質障害でも強度差の域值は高くなるが成立する 例があり，音圧といらものの感覚中枢は聴皮質以外の部 位にもあるのかもしれない.

耳が 2 戞意味は大きい。われわれのように“耳” のすべてを扱っている耳科医は，耳に障害のある人々に
ぜひとも再び両耳が使えるよらにすることを目標に考学 るべきではないかと思う。その際，方向感検査は良い尺 度であり，利用をすすめたい。

\section{参考文献}

1) Gulick WL : Hearing, physiology and psychoplysics. pp 181 185, Oxford University Press, New York, 1971.

2 ) Stotler WA : An experimental study of the cell and connection of the superior olivary complex of the cat. J Comp Neurology 98 : 401 420, 1953.

3 ) Galambos R, Schwartkopf J and Rupert A : Microelectrode study of superion olioary nuclei. Am J Physiol $197: 527 \sim 536,1959$.

4) Van Bergeijk WA : Vauation on a theme of Békésy; a model of binaural interaction. J Acoust Soc Am 34 : 1431 1437, 1962.

5 ) Békésy GV : Experiments in hearing. Mc Graw-Hil, New York, 1960.

6) Osen KK : The intriusic organization of the cochlear nuclei in the cat. Acta Otolaryngol $67: 352 \sim 359,1969$.

7 ) Casseday JH and Covey E : Central auditory pathways in directional hearing. In Directional Hearing (ed by Yost WA and Gourevitch G). pp 109 143, Springer-Verlag, NY Berlin, Tokyo, 1987.

8 ）竹尾康男：音の聴こえの方向感に関する研究(その 1 ). 日 耳鼻 $67:$ 106〜117, 1964.

9 ) 竹尾康男: 音の聴こえの方向感に関する研究(その 2 ). 日 耳鼻 $67: 1272 \sim 1283,1964$.

10）寺尾 樹：両耳聴に打ける音像移動弁別域值に関する研究. 日耳鼻 $67: 982 \sim 991 ， 1964$.

11）切替一郎, 設楽哲也, 竹尾康男, 他：音像成立機転に関寸 る基礎的研究と臨床的応用. Audiology Japan $7: 1 \sim 5$, 
1964.

12）設楽哲也：方向感検査法拉よび一側歪語音検査法による感 音性難聴の細別診断. 日耳鼻 $69: 51 \sim 69,1966$.

13) Kirikae I, Sato $T$ and Shitara $T: A$ study of hearing in advanced age. Laryngoscope $74: 205 \sim 220,1964$.

14）佐藤恒正，鈴木秀明，八幡則子，他：新しい方向感検査装 置及びその応用. Audiology Japan $26: 659 \sim 666,1983$.

15) Kaga M : Development of sound localization. Acta Paediatr Jpn 34 : 134 138, 1992.

16）久松雄志, 谷野 徹, 佐々木智, 他 : 加齢と方向感. $\mathrm{Au}$ diology Japan 40 : 335 336, 1997.

17）加我君孝, 中村雅子：聴覚障害. 新老年学第 2 版（編集代 表折茂 肇). 484 502頁, 東京大学出版会, 1999.

18）水谷俊雄 : 脳の加秢 一バランスとアンバランスー。神経 精神薬理. $18: 169 \sim 177$ 頁, 1996.

19）武田英彦：片側あるいは両側の難聴者に打ける両耳聴の研 究一伝音性, 感音性, 神経性難聴之音像定位一. 東京大 学医学系研究科. 学位論文, 1999.

20) Hausler R, Colburn HS and Marr E : Sound localization in subjects with impaired hearing. Acta Otolaryngol Suppl 400, 1 62, 1983.

21) Zurek PM : Consequences of conductive auditory impairment for binaural hearing. J Acoust Soc Am 80 : 466 472, 1986.

22) Gabriel KJ, Koehnke J and Colburn HS : Frequency dependence of binaural performance in listeners with impaired binaural hearing. J Acoust Soc Am 91 : 336 347, 1992.

23) Koehnke J, Culotta CP, Hawley ML, et al : Effects of reference interaural time and intensity differences on binaural performance in listeners with normal and impaired hearing. Ear Hear 16:331 353, 1995.

24）岡村るみ, 中村雅一, 加我君孝 : 外耳道形成術後の補聴器 装用下の音像定位. 耳鼻臨床 $90: 277 \sim 283,1997$.

25）瀬藤光利, 加我君孝 : 両側性小耳症外耳道閉鎖症例の両側 骨導補聴器による音源定位. Audiology Japan $38: 669$ 670, 1995.

26) Gelfand SA : Long-term recovery and no recovery from the auditory deprivation effect with binaural amplification; six cases. J Am Acad Audiol 6 : 141 149, 1995.

27）切替一郎, 佐藤恒正, 大島弘至, 他 : 補聴器装着時の方向 感について. 日耳鼻 $67: 29 \sim 31,1964$.

28）佐藤恒正, 飯塚尚久, 下田雄大, 他 : 方向感検査による小 脳橋角部腫瘍の早期診断. 耳鼻臨床 $87: 9 \sim 22,1994$.

29）山田勝士, 加我君孝 : 聴神経, 脳幹障害患者の両耳間時間 差音像定位と ABR 波形異常の検討. Audiology Japan 34 : 238 243, 1991.

30）武田英彦，熊川孝三，加我君孝：聴神経腫瘍に扝ける時間
差および強度差による音像定位検査一ABR 波形異常との 比較を中心に一. 日耳鼻 $99:$ 18～27, 1996.

31) Kaga K, Nakamura M, Shinogami M, et al : Auditory nerve disease of both ears revealed by auditory brainstem responses, electrocochleography and otoacoustic emissions. Scand Audiol 25 : 233 238, 1996.

32) Starr A, Picton TW, Sininger Y, et al : Auditory neuropathy. Brain $119: 741 \sim 753,1996$.

33) Schuknecht HF and Woellner RC : Hearing losses following partial section of the chochlear nerve. Laryngoscope $63: 441 \sim 465,1953$.

34) Van Der Poel JC, Jones SJ and Miller DH : Sound lateralization, brain stem auditory evoked potentials and magnetic resonance imaging in multiple sclerosis. Brain $111: 1453 \sim 1474,1988$

35) Levine RA, Gardner JC and Kiang NYS : Binaural auditory processing in multiple sclerosis subjects. Hear Res $68: 59 \sim 72,1993$

36) Levine RA, Gardner JS and Kiang NYS : Effects of multiple sclerosis brain stem lesions on sound lateralization and brainstem auditory evoked potentials. Hear Res $68: 73 \sim 88,1993$.

37) Russolo M and Doli P : Lateralization, impedance, auditory brain stem responce and synthetic sentence audiometry in brain stem disorders. Audiology $22: 50 \sim 62,1983$.

38) Masterton B, Jane JA and Diamond IT : Role of brain stem auditory structures in sound lateralization; trapezoid body, superior olive, and lateral lemniscus. J Neurophysiol $30: 341 \sim 359,1967$.

39) Yamada K, Kaga K, Uno A, et al : Sound lateralization in patients with lesions including the auditory cortex ; comparison of interaural time difference (ITD) discrimination and interaural intensity difference (IID) discrimination. Hear Res 101 : 173 180, 1996.

40) Sanchez-Longo LP and Foster FM : Clinical significance of impairment of sound localization. Neurology $8: 119$ $\sim 125,1958$.

41) Klingon $\mathrm{GH}$ and Bontecou DC : Localization in auditory space. Neurology $16: 879 \sim 886,1966$.

42) Shankweiler DP : Performance of brain-damaged patients on two tests of sound localization. J Comp Physiol Psychol 54 : 375 381, 1961

43) Gazzaniga MS, Glass AV, Sarno MT, et al : Pure word deafness and hemispheric dynamics; a case history. Cortex $9:$ 136 143, 1973.

44) Walsh, E.G. (1957) An investigation of sound localization in patients with neurological abnormalities. Brain $80: 222$ $\sim 250$. 
45) Bisiach E, Cornacchia L, Sterzi R, et al : Disorders of perceived auditory lateralization after lesions of the right hemisphere. Brain $107: 37 \sim 52,1984$.

46) Jerger J, Weikers NJ, Sharbrough III FW, et al : Bilateral lesions of the temporal lobe; a case study. Acta Otolaryngol Suppl (Stockh) $258:$ 1 51, 1969.

47) Jerger J, Lovering L and Wertz $\mathrm{M}$ : Auditory disorder following bilateral temporal lobe insult; report of a case. J Speech Hear Disord 37 : 523〜 535, 1972.

48）及川 尚：音方向感の研究一特に一側難聴, 一側襲につ いて一. 日耳鼻 $93: 361 \sim 372,1990$.

49) Jongkees LBW and Veer RA : Directional hearing capacity in hearing disorders. Acta Otolaryngol $48: 465 \sim 474$, 1957.

50）服部 浩：一側龍の方向感. 臨床耳鼻 $11: 314 \sim 315,1984$.

51）大内 仁, 武山貢次, 立木 孝, 他 : 聴覚による音方向知 覚に関する研究. 日耳鼻 $60: 241 \sim 249,1956$.

52) Lessand N, Paré M, Lepore F, et al : Early-blind human subjects localize sound sources better than sighted subjects. Nature $395: 278 \sim 280,1998$.

53）矢部多加夫, 小泉達郎: 視覚障害者の方向感について. Audiology Japan 41 : 485 486, 1998.

54) Röder B, Teder-Salejarviw, Hilliyard SA, et al : Improved auditory spatial tuning in blind humans. Nature 400 : $162 \sim 165,1999$.

55）菊野宏一：究極のバイノーラル録音入門. Stereo 2 月号 : $130 \sim 134,1990$.

56) Zuccarelli $\mathrm{H}$ : Ears hear by making sounds. New scientist $10: 438 \sim 440,1983$

57) Heffner RS, Heffner HE, Kearns D, et al : Sound localization in chinchillas. I; left/right discriminations. Hear Res 80 : 247 257, 1994.

$$
\begin{aligned}
& \text { (別刷請求先 : 加我君孝 } \\
& \text { 个113-0333 東京都文京区本郷7-3-1) } \\
& \text { 東京大学耳鼻咽喉科学教室 }
\end{aligned}
$$

